\title{
A Study on Disclosure of Intangible Assets in 5 Star Hotels in Bangalore
}

\author{
Mugdha Kulkarni* \& Vaybhav Malhotra†
}

\begin{abstract}
:
This research helps to provide the information about tangible and intangible assets in 5 star hotels in Bangalore. This research shows that computer software are the main intangible assets used by the organizations. This research uses both primary and secondary data. The primary data tool was telephonic interview of five star hotels in Bangalore. The secondary data included annual reports of the hotels, books, journals. In Secondary data the tangible assets, intangible assets \& Earning per Share (EPS) information was taken and analyzed using correlation. The research helps to know that the information on intangible assets are partially disclosed and it also shows that the EPS of all the companies are highly influenced by various tangible and intangible assets that the company has.
\end{abstract}

Keywords: Tangible Assets, Intangible assets, Earning per share (EPS)

\section{Introduction}

Individuals/Companies spend money on tangible assets (also known as hard assets) because they are generally regarded more constant in value than the most generally exchanged sovereign foreign exchange and investments. When the world financial

\footnotetext{
* Assistant Professor, Department of Tourism Studies, Christ University, Bengaluru, India; mugdha.shailendra@christuniversity.in

† vaybhav.malhotra35@gmail.com
} 
system falters, many traders move into concrete resources, such as silver, because they are recognized as safe havens during difficult financial times.

But in the present scenario, intangible assets such as brand culture, knowledge and so on are also a significant part of a business. The companies invest in the intangible assets to provide value-added products and services. Basically, the investors should know or understand the emerging importance of intangible assets and the corporate value and growth resulting from them. Intangible Assets are those assets which cannot be seen, touched, or felt, as it does not have any physical form etc. Disclosure of intangible assets on the assets side of the balance sheet can add value to the company's net worth.

\section{Need for study}

This study focuses on understanding the various intangible assets in hotel industry and the methods or approaches deployed to value them. The accounting procedures of the hotel industry regarding the disclosure of intangible data are also discussed through this study.

\section{Scope of the study}

This study focuses on the intangible assets in five-star hotels in Bangalore.

\section{Objectives of the study}

To study the disclosure of intangible assets in the balance sheets.

To identify the companies, those are voluntarily disclosing the intangible assets data.

To study how the Earning per Share affects the tangible and intangible assets 


\section{Review of Literature}

Belfrage, Erice E; O,Neill, J. (2005) have detailed about the existing intangible assets' value in the hotel. Through this paper, the researchers discuss on how to estimate and identify the value of an intangible asset. Secondary data was collected from the audit report, financial statement and other reports of two new hotel franchisees. The researcher started analyzing and comparing the revenue and expenditure of the hotel franchise. The study concluded by suggesting that if the hotel franchise revenue is more than expenditure, it portrays the performance and services of the hotel.

Hua, N (2007) in his thesis throws light on the valuation of the intangible assets in the hotel industry in the US. The study was about evaluation of the firm's tangible and intangible assets. The significant difference of contribution from adjusted income derived from tangible assets (AIT) and adjusted income derived from intangible assets (AII) are equated to a firm's market value equity. The value of the firm's intangible assets is equal to the market value of equity shares and liabilities. The source of data collections are financial reports and the data was interpreted using statistical techniques such as regression and correlation.

The formula used is:

Adjusted income derived from intangible assets (AII) $=$ Equity Share +Liabilities - Book Value of Tangible Assets

It is assumed that the firms have applied a uniform capital structure across their Tangibles and Intangible assets.

M Jerman, S Kavcic, B Kavcic (2009) have explained the significance of intangible assets in hotel industry. The research covered the period from 2004 to 2008 . The study majorly considered the growth of intangible assets in hotels. The scope of the study was Croatian, Slovenian and Austrian hotel industry. It was a comparative study of large hotel's company's intangible assets and small hotel's company's intangible assets. The results concluded that intangible asset's values is not of much significance to the industry.

Truls E.J. Engström, Petter Westnes, Siren Furdal Westnes, (2003) undertook a single embedded case study with the major objective 
of evaluating the intellectual capital of 13 hotels in the Radisson SAS Hotels and Resorts hotel chain. By using the multiple source data, the study investigated the knowledge and data produced by evaluating the intellectual capital, and explored the potential relationship between intellectual capital and performance of the business. The results conclude that it is possible to evaluate intellectual capital in a hotel business, and the knowledge and data from the intellectual capital evaluation provide useful information regarding the identification of local areas, resource allocation, strengths and weaknesses, bench marking, and managing the future. The findings indicate that it is useful to evaluate a hotel's intellectual capital due to its potential relationship with business performance.

H Kim, WG Kim, (2005) state the growing emphasis on building and managing brand equity as the primary drivers of a hospitality company's success. Success in brand management results from understanding brand equity correctly and managing them to produce solid financial progress. This study examines the underlying dimensions of brand equity and how they affect a firms' performance in the hospitality industry in particular like luxury hotels and chain restaurants. The conclusion of this study indicates that brand loyalty, brand equity, perceived quality, and brand image are important components of customer-based brand equity. A good relationship was found to exist between the components of customer-based brand equity and the firms' performance in luxury hotels and chain restaurants. A different scenario was delineated from the relationship between the components of customer-based brand equity and firms' performance in luxury hotels and chain restaurants.

M Joonho (2011) has explored the franchising and non-franchising of the intangible assets in retail sales. The study was on the financial performance of the company investigating the profitability and the intangible assets value of the franchise and non-franchise. Secondary data was collected from the company's financial statements and reports from 2001 to 2009. The variables are leverages, firm size, intangible values etc. The researcher compares the financial statements and reports of the franchising and non-franchise companies and concluded that the franchising 
companies have higher profitability and intangible values than non-franchise companies.

Hua (2007) has explored the effect of marketing expenditure on hotel's firm value. Marketing expenditure is important to intangible assets that are related to service innovation, customer loyalty, customer satisfaction, and so on. The inflow, the future profit and value of the firm findings were the intangible assets that are important in the hotel industry. Marketing expenditure behaves differently from other expenditure and is more important to determine if they are able to generate profits or not.

Krystin Zigan, Dia Zeglat, (2010) conducted a study with an objective to demonstrate the value of intangible resources and subsequently its importance in integration of performance measurement systems applied in the hotel industry. Based on the review of literature, arguments were drawn on relevant theories in performance measurement in the hotel industry and the concept of intangible resources. Merging the two different concepts reveals new research areas. The literature review shows that even those integrated performance measurement systems that aim to include non-financial measures do not necessarily capture intangible resources. Based on the finding, suggestions for extending performance measurement systems have been made. This paper has significant implications for managers, as it will allow them to broaden their perspective and include important performance drivers (i.e. intangible resources such as knowledge, social capital and so on) in their performance measurement systems. The paper highlights the need for a comprehensive performance measurement approach that comprises indicators for measuring intangible resources and suggests tools that better capture the contribution of these important performance drivers.

Michael C. Dalbor (2011) undertook a study with an aim to examine the investment actions with regard to accommodation companies and their product value. Common least pieces and twostage least pieces, regressions are used. The reliant varying is institutional trader amount and the separate factors are marketing expenses, size, investment expenses, proxies, financial debt rate, price, share revenues and year. The research found that institutional investors' holdings are favorably related to marketing 
expenses. Organizations benefit accommodation companies that have low financial debt percentages. Institutional traders prefer small companies because they typically offer excellent profits. Further analysis may be done to see whether individual traders benefit companies with product value. Additional analysis may be performed in other sections, such as dining places or gambling houses. Results may help accommodations supervisors in increasing investment decision from institutional investors; scientists in performing future analysis on institutional investors; and teachers in better explaining institutional investors' important position to students. The paper is the first to show a relationship between institutional traders and marketing expenses in the accommodations industry.

Shital Jhunjhunwala, (2009) has focused on providing a strategy to manage intangible assets (IAs) resource that are a key value for a company. With the help of three different illustrations, it made efforts to analyze the cause-and-effect and interrelationship among different intangibles and map them to business achievements. The document notices that the achievements of any company relies on a system of connected IAs that impact each other and the core is to ensure that each of these execute as preferred. The use of a causal design clearly shows the cause-and-effect connections between key factors and greatest goals, and helps companies recognize which intangibles need to be regularly supervised using appropriate signs to get the goals. The designs have not been confirmed in exercise. The signs shown can be used to track the efficiency of intangibles. Three market specific unique general designs are provided that are useful to supervisors and professionals as a foundation for determining and applying key intangibles (value drivers) to their company goals.

Bram Boekestein, (2006) evaluates the exposure of intangible resources on the balance-sheet of drug organizations. The paper further explores how these resources overlap with perceptive investment and whether a link can be recognized between intangible resources and an organization's efficiency. Intangible resources confirming methods of 52 worldwide working drug organizations are examined. These resources are relevant to perceptive investment explanations and organization efficiency. Results indicate that most 
organizations are specifying intangible resources and that a significant overlap happens with perceptive investment. Intangible resources may considerably represent a company's resources. However, clear interaction of intangible resources with organization efficiency could not be recognized. Flaws in the confirming of intangible resources are noticed. These are the non-uniformity of generally decided bookkeeping concepts and exercises around the world, the requirements of a good reputation and the place of R\&D. A number of suggestions are put ahead to enhance the exposure of intangible resources and to bring these in line with perceptive investment explanations. The value of the document can be found in the strategy to satisfy the perfect of perceptive investment assessment through the more realistic way of intangible resource requirements on the balance-sheet. This research analyzes the situation in 2003 for a number of organizations and the way ahead to further enhancement.

According to Subhas, C., Vishakha, M. (2011) India has emerged at the top in the existing knowledge-driven international industry, where intangible resources have much more value than actual resources. The purpose of this research is to figure out the level of intangible resource disclosure by organizations in India. This research covered the period 2002-2008 and included 243 organizations chosen from BT-500 organizations. The yearly reviews of these organizations were examined using material research so as to analyze the level of disclosure of intangible resource details. This research used a customized intangible resources disclosure catalog, which had been made in accordance with the intangible resources structure given by Sveiby (1997) and as used and examined by Guthrie and Small (2000) and many others following research. The outcomes revealed that exterior investment is the most revealed intangible resource classification with a disclosure ranking of $37.90 \%$ and $35.83 \%$ for $2003-04$ and 2007-08 respectively. Infosys technological innovation Ltd. is the company with the biggest intangible resources confirming for both the decades (2003-04: 68.52\%, 2007-08: 81.48\%). Further the confirming of intangible resources is disorganized and unsystematic. There is deficiency of appropriate structure for exposing intangible resources details in the yearly reviews. This is perhaps the first extensive research on intangible resources 
disclosure depending on a large example of the organizations from India. Literary works reveal that now the intangible resources play relatively a more and more important part in the decision making procedure of various customers of business reviews. This research reveals that the overall disclosure of intangible resources is low in India. Thus this research may be of value to the business industry in India to identify the areas of intangible resources disclosure so that they can provide useful and appropriate details to the customers of yearly reviews.

Luiz Antonio Joia, (2000) came out with a research that marked the beginning of a trend. Since the publication of his article, several years of research has been performed in order to determine a possible and efficient direction to evaluate the intangible resources of an organization, also known as its perceptive investment. Several designs have been described in this pioneering research, though problems still need to be fixed. In this article a heuristic structure dealing with the web link between perceptive investment and business technique is designed, according to the author's suggested intangible business resource taxonomy. This design is used by an organization within the mineral magnesium market. The "time-lag trap" problem is provided to highlight the misunderstandings arising out of the fixed rather than the powerful intangible resource pricing technique. Upcoming styles such as the development of the IC (Intellectual Capital) flexibility idea and some results in this world are also provided.

Annie Green, Julie J.C.H. Ryan, (2005) describe the adequacy of current intangible resource designs and describe and codify typical major assessment motorists of intangible sources for use in company health scorecard assessment methods of technology (IT) companies. Existing intangible resource balance scorecard assessment designs and value sequence designs are analyzed to draw out their value elements and arrange them with performance-based activities of the corporation to determine a typical taxonomy of value motorists of intangible sources. CEOs, primary finance authorities, CFOs and "other executives" of IT companies confirm the nomenclature. IT companies that use a standard and reliable nomenclature of intangible sources could increase its ability to recognize and account for more intangible sources for statistic 
and assessment purposes. This research is restricted to the California Urban Area and is a single industry research (IT firms) whose focus on the market is CEOs and CFOs; and focus is on the Ranking Card type model as categorized by Sveiby. Future studies could cover a large geographical area, the opportunity to other industries, and the focus on market to other decision creators. The structure of intangible assessment areas (FIVA) allows a company to recognize and link efficiency measurements/ indicators to its intangible value. It provides a structure to have control of and access to effective usage of company sources and information, to create, maintain and improve its objective efficiency and/or aggressive advantage.

Verna Allee, (2008) offers illustrations and technological details for using a value system research that details the transformation and utilization of intangible resources. Value system research was first developed in 1993 and was tailored in 1997 for intangible resource control. It has been examined in programs from shop floor work categories to company internets and economic areas. It is inspired from a concept based in living systems, information control, complexness concept, system characteristics, and intangible resource control. The document provides an advanced level of detail on the research technique and ideas from its program across a range of company issues. Tips are offered as to how to incorporate the technique in other company research techniques. This research is the first specific material on the value system research technique, which has been recommended by experts in intangibles, system research, information control, and procedure research. It fills up a gap between concept and practice for supervisors, professionals, experts, and scientists

\section{Research Methodology}

\section{Data Collection:}

Primary Data: - The interview method was adopted to do a primary survey which was from accounts office or assistant accounts or accounts manager. 
Secondary Data: - Secondary Data was collected from the annual reports of the Indian Hotel Company Limited by Tata Enterprise \& The Oberoi Hotel Group for the year 2013-14.

\section{Findings and Suggestions}

\section{Intangible assets are not the key element in decision making in} spite of hotels incurring expenses for acquiring the same.

In the hotel industry, computer software used in the industry forms $37.5 \%$ of the intangible assets used by the industry. Business rights and service \& operating rights used by IHCL form $12.5 \%$ each. Website development costs used by IHCL \& Hotel Leela Venture form $25 \%$. The License/Franchise Fee are only intangible assets used by The Oberoi Hotel Group which form 12.5\%. The IHCL invested in intangible assets is 0.154 i.e. $49 \%$ and this is the hotel which invested highest in intangible assets. The hotel Leela venture has intangible assets of 0.15 i.e. $47.46 \%$ and this is the hotel which invested second highest in intangible assets. The Oberoi hotel investment in intangible assets is 0.012 i.e. $3.79 \%$ and this shows that the company is not interested in investing in intangible assets.

IHCL data also shows that the intangible assets help in making the decision.

However, Hotel Leela and the Oberoi group do not value intangible assets and disclosure of the same is not seen in the balance sheet and hence intangible assets is not a criteria while making management levels decisions.

All the hotel companies use Micros Fidelio for accounting as well as booking \& reservation. All the hotel companies disclose the information of intangible assets in the annual report. Cost method is used for valuation of intangible assets.

\section{Correlation between tangible and intangible assets}

1. Indian Hotel Company Limited 
Table 1-Shows the calculation of correlation to compare tangible and intangible assets in the period 31 March 2013 to 31 March 2014 for IHCL.

\begin{tabular}{|l|c|c|}
\hline & Tangible Assets & Intangible Assets \\
\hline 31 March 2013 & 1 & 1 \\
\hline 31 March 2014 & -1 & -1 \\
\hline
\end{tabular}

- In 31 March 2014 the correlation is negative as compared to 31 March 2013 because the earning per share (EPS) is diluted in 31 March 2014 as compared to 31 March 2013.

- The EPS in 31 March 2014 was 3.71 and the same was 1.91 as of 31 March 2013 because the profit of IHCL had decreased.

- The disposal and depreciation of tangible assets was more in 31 March 2014 than in 31 March 2013 and the amortization of intangible assets was more in 31 March 2014 than 31 March 2013.

- On 31 March 2013, there is a positive correlation for tangible as well as intangible assets but on 31 March 2014 there is a negative correlation for tangible as well as intangible assets.

\section{EIH Group of Hotels}

Table Shows calculation of correlation to compare tangible and intangible assets as on 31 March 2013 and 31 March 2014 for EIH

\begin{tabular}{|l|l|l|}
\hline & Tangible Assets & Intangible Assets \\
\hline 31March 2013 & 1 & 1 \\
\hline 31 March 2014 & 1 & 1 \\
\hline
\end{tabular}

- On 31 March 2014 the correlation is positive as it was on 31 March 2013 because the earning per share (EPS) is positive in 31 March 2014 as compared to 31st March 2013.

- The EPS on 31 March 2014 was 0.89 and on 31 March 2013 was 1.1 because the profits were calculated before extraordinary items of the IHCL has decreased.

- The disposal and depreciation of tangible assets was reduced in 31 March 2014 than 31 March 2013 and the 
amortization of intangible assets was less oin 31 March 2014 than 31 March 2013.

- The correlation for both the years are positive

\section{Suggestions}

- The Hotels should disclose the name of the computer software they use

- They must also mention the terms of the computer software

- The organizations can work on their intangible to improve current accounting

\section{Conclusion}

The research shows that computer software are the main intangible assets used by the organizations. The study shows that cost method is mainly used in valuation of intangible assets of the companies. It shows that EPS and the amount of tangible and intangible assets a company has are inter-related. The research concludes that the information on intangible assets is only being partially disclosed and it also shows that the EPS of all the companies are highly influenced by various tangible and intangible assets that the company has. Since hospitality being a human resource based industry more intangible assets should be disclosed which will help companies increase shareholder's wealth.

\section{References}

Annie Green, Julie J.C.H. Ryan, (2005) "A framework of intangible valuation areas (FIVA): Aligning business strategy and intangible assets", Journal of Intellectual Capital, 6 (1), pp.43 - 52

Annie Green, (2007) "Intangible assets in plain business language", VINE, Vol. 37 (3), pp.238 - 248

Baruch Lev, Juergen H. Daum,_(2004) "The dominance of intangible assets: consequences for enterprise management and corporate reporting", Measuring Business Excellence, 8 (1), pp.6 - 17

Basak Denizci Guillet, Marketing outlays: Important assets in the 
hotel industry?

Belfrage, Erice E; O,Neill, J. (2005). A Strategy for Estimating Identified Intangible Asset Value: Hotel Affiliation Contribution. The Appraisal Journal, winter 2005.

Bram Boekestein, (2006) "The relation between intellectual capital and intangible assets of pharmaceutical companies", Journal of Intellectual Capital, Vol. 7 (2), pp.241 - 253

Carlos Serrano Cinca, Cecilio Mar Molinero, Alexandre Bossi Queiroz,_(2003) "The measurement of intangible assets in public sector using scaling techniques", Journal of Intellectual Capital, 4 (2), pp. 249 - 275

Frances Kennedy, (1998) "Intellectual capital in valuing intangible assets", Team Performance Management: An International Journal, 4 (4), pp.121 - 137

Gita Mathur, Kam Jugdev, Tak Shing Fung, (2007) "Intangible project management assets as determinants of competitive advantage", Management Research News, 30 (7), pp.460- 475.

Giustina Secundo, Alessandro Margherita, Gianluca Elia, Giuseppina Passiante, (2010)

Hua, N., Denizci, B., Mattila, A., \& Upneja, A. (2008). Marketing Outlays: Important Intangible Assets in the Hotel Industry? Journal of Quality Assurance in Hospitality \& Tourism, 61

H Kim, WG Kim, (2005), “The relationship between brand equity and firms' performance in luxury hotels and chain restaurants", Journal on Tourism Management, 26 (4) Pp 549-560 health", Journal of Intellectual Capital, 9 (3), pp.351 - 366.

Hua, N (2007), "Valuation of Intangible Assets for publicity traded hotel firms in the United States (US)"

Isabel Gallego, Luis Rodríguez,_(2005) "Situation of intangible assets in Spanish firms: an empirical analysis", Journal of Intellectual Capital, 6 (1), pp.105 - 126

Jeremy Galbreath, (2002) "Twenty-first century management rules: the management of relationships as intangible assets", Management Decision, 40 (2), pp.116 - 126

Krystin Zigan, Dia Zeglat, (2010) "Intangible resources in performance measurement systems of the hotel industry", 
Facilities. 28 (13/14), pp.597 - 610

Luiz Antonio Joia, (2000) "Measuring intangible corporate assets:

Linking business strategy with intellectual capital", Journal of Intellectual Capital, Vol. 1(1), pp.68 - 84

M Jerman, S Kavcic, B Kavcic (2009): Intangible as future value creators: The case of the hotel industry. Pp 153-162.

Michael C. Dalbor Do institutional investors favor firms with greater brand equity? An empirical investigation of investments in US lodging firms International Journal of Contemporary Hospitality Management (Impact Factor: 0.93). 02/2010; 22(1):2440.

Michiel Schoemaker, Jan Jonker, (2005) "Managing intangible assets: An essay on organising contemporary organisations based upon identity, competencies and networks", Journal of Management Development, 24 (6), pp.506 - 518

Norhana Salamudin, Ridzwan Bakar, Muhd Kamil Ibrahim, Faridah Haji Hassan,_(2010) "Intangible assets valuation in the Malaysian capital market", Journal of Intellectual Capital, 11 (3), pp.391 - 405

Pamela Cohen Kalafut, Jonathan Low, (2001) "The value creation index: quantifying intangible value", Strategy $\mathcal{E}$ Leadership, 29 (5), pp. 9 - 15

Petros A. Kostagiolas, Stefanos Asonitis, (2009) "Intangible assets for academic libraries: Definitions, categorization and an exploration of management issues", Library Management, Vol. 30 (6/7), pp.419- 42

Shital Jhunjhunwala, (2009) "Monitoring and measuring intangibles using value maps: some examples", Journal of Intellectual Capital, 10 (2), pp.211 - 223

Subhas, C.; Vishakha, M. (2011). A study on intangible assets disclosure: An evidence from Indian companies. Intangible Capital, 7 (1):1-30.

Suraksha Gupta, Susan Grant, T.C. Melewar, (2008) "The expanding role of intangible assets of the brand", Management Decision, 46 (6), pp.948 - 960

Susanne Durst, (2008) "The relevance of intangible assets in German SMEs", Journal of Intellectual Capital, 9 (3), pp.410 - 432 
Truls E.J. Engström, Petter Westnes, Siren Furdal Westnes, (2003) "Evaluating intellectual capital in the hotel industry", Journal of Intellectual Capital, 4 (3), pp.287 - 303

Verna Allee, (2008) "Value network analysis and value conversion of tangible and intangible assets", Journal of Intellectual Capital, 9 (1), pp.5 - 24

The Waray Culture of the Philippines. (n.d.). Retrieved November 24, 2015, from http://www.academia.edu/ 8631312/The_ Waray_Culture_of_the_Philippines

Website:

Intangible Assets Accounting | Amortization - AccountingTools. (n.d.). Retrieved November 24, 2015, from http:// www.accountingtools.com/intangible-assets-accounting (n.d.).

Retrieved November 2, 2014, from http:// scholarworks.umass.edu/ cgi/viewcontent.cgi? article $=1023 \&$ context=gradconf_hospitality

(n.d.). Retrieved November 23, 2013, from http://scholarworks.umass.edu/cgi/viewcontent.cgi?Article $=1023 \&$ context $=$ gradconf_hospitality

Retrieved December 24, 2013, from http:// scholarworks.umass.edu/ cgi/viewcontent.cgi? article $=1023$ \&context=gradconf_hospitality (n.d.).

Retrieved Jan 16, 2014, from http://scholarworks.umass.edu/ cgi/viewcontent.cgi?article=1023\&context=gradconf_hospitality

(n.d.). Retrieved November 4, 2014, from http:// scholarworks.umass.edu/cgi/viewcontent.cgi?article=1 023\&context=gradconf_hospitality

Invest on intangible asset building. (2011, January 5). Daily News (Colombo, Sri Lanka). Retrieved February 24, 2014, from http://www.highbeam.com/doc/1G1-247377144.html? 